\title{
RUSSELL, EINSTEIN AND THE PHILOSOPHY OF NON-ABSOLUTE PACIFISM
}

\author{
David Blitz \\ Philosophy and Honors Program / Central Connecticut State U. \\ New Britain, CT 06050, USA \\ BLITZ@MAIL.CCSU.EDU
}

Russell and Einstein shared a commitment to a form of pacifism which Russell termed "non-absolute pacifism", or "relative political pacifism". Despite a 1947 disagreement on the roles of the United States, the Soviet Union and the immediate measures to be taken for world peace, Russell and Einstein were able to collaborate again in I955 due to their shared philosophy. Newly discovered annotations by Einstein on a 1947 Russell article are used to analyze their disagreement, while their later statements are used to illustrate their shared commitment to a type of pacifism which allowed, exceptionally, for a justified war in the special circumstance of an enemy opposed to "life as such".

\section{INTRODUCTION}

$\mathrm{O}$

n 9 July I955 Bertrand Russell held a press conference at Caxton Hall, Westminster, where he presented a statement against nuclear world war, co-signed by Albert Einstein and nine other leading scientists, all but one of whom were or eventually became Nobel

${ }^{1}$ I wish to thank Carl Spadoni of Archives and Research Collections, McMaster U. Library, for help in locating documents used in this article, as well as the Editor. Permission to quote from Einstein's 1947 letter to Russell was granted by The Albert Einstein Archives, Jewish National and University Library, Hebrew U. of Jerusalem. 
prizewinners. ${ }^{2}$ The statement ended with a resolution:

In view of the fact that in any future world war nuclear weapons will certainly be employed, and that such weapons threaten the continued existence of mankind, we urge the Governments of the world to realize, and to acknowledge publicly, that their purposes cannot be furthered by a world war, and we urge them, consequently, to find peaceful means for the settlement of all matters of dispute between them. ${ }^{3}$

The Russell-Einstein statement (or manifesto, as it is also known) was widely reported in the press. ${ }^{4}$ It was significant not only for the fame of its two principal signatories, but also because of the signature of Frederic Joliot-Curie, a Nobel prizewinner in chemistry and a member of the French Communist Party. 5 This the first time both non-Communist and Communist scientists had signed a joint declaration against nuclear and world war. This event was followed up by a World Conference of

${ }^{2}$ The complete list of signatories, with their country of residence and Nobel Prize (where awarded) was: Russell (UK I950, literature), Einstein (US 1921, physics), Percy W. Bridgman (US 1946, physics), Hermann J. Muller (Us 1946, physiology and medicine), Cecil F. Powell (UK 1950, physics), Joseph Rotblat (UK 1995, peace), Frederic JoliotCurie (France 1935, chemistry), Leopold Infeld (Poland), Hideki Yukawa (Japan 1949, physics), Max Born (Germany 1954, physics), Linus Pauling (US 1954, chemistry; 1962, peace). In the hurried days leading up to the finalization of the list, Russell inadvertently left out Born's name, an omission which he subsequently corrected.

${ }^{3}$ Russell, "Scientists Appeal for Abolition of War", Bulletin of the Atomic Scientists, II (Sept. 1955): 237 .

4 The transcript of the press conference is entitled "Press Conference by the Earl Russell at Caxton Hall, Westminster on Saturday, 9th July 1955". It includes a brief prefatory remark by Joseph Rotblat followed by Russell's presentation of the statement, prefatory remark by joseph Rotblat followed by Russell's presentation of the statement, also released as a recording entitled Notice to the World with the subtitle "... renounce war or perish! ... world peace or universal death!" (Audio Masterworks LPA I225).

5 The Russell-Einstein manifesto was not the only protest against nuclear and world war. Lawrence S. Wittner in Resisting the Bomb: a History of the World Nuclear Disarmament Movement 1954-1970 (1997), Vol. 2 of his exhaustive The Struggle against the Bomb (Stanford: Stanford U. P., 1993), indicates other actions in the period 1954-56, which he terms a period of "the gathering storm" against nuclear weapons. In particular, a parallel appeal was organized by Max Born, assisted by Otto Hahn, which led to the July I95s conference of Nobel laureates, who presented the declaration known as the Mainau Declaration, from the town in Germany where 18 of them met. Eventually, 52 Nobel laureates signed it, though, lacking Einstein's name and limited to non-Communists, its impact was not as great as that of the Russell-Einstein resolution. See Wittner, 2: 7.
Scientists on the same topic, held at County Hall, London, on 3-5 August 1955, which was the first meeting on the problem of nuclear world war to attract scientists from both the West and the East. ${ }^{6}$ This tradition was continued through the Pugwash Conferences (awarded the Nobel Prize for Peace in 1995), which were organized in direct response to the Russell-Einstein resolution when the Canadian-American industrialist Cyrus Eaton offered his summer house at Pugwash, Nova Scotia, for this purpose. The Russell-Einstein manifesto was all the more poignant for the fact that it was the last document Einstein signed before his death. Russell's description of the last occasion that he interacted with Einstein is touching:

I was among those who almost always agreed with him. He and I both opposed the First World War, but considered the Second unavoidable. He and I were equally perturbed by the awful prospect of $\mathrm{H}$-bomb warfare. We agreed to make a joint pronouncement on this subject in conjunction with any eminent men of science who were willing to cooperate. I drew up a statement and sent it to Einstein. Before getting an answer from him, while travelling by air from Rome to Paris, I learnt of his death. On arrival in Paris, I found his letter agreeing to sign. This must have been one of the last acts of his life. ${ }^{7}$

Russell placed the emphasis here on his agreements with Einstein, which were substantial and based on a common adherence to a form of non-absolute pacifism. This paper will consider the history of the Russell-Einstein cooperation, with emphasis on a disagreement in 1947 on the advisability of acting jointly against the danger of war-eight years before their final collaboration. ${ }^{8}$ In considering this disagreement,

${ }^{6}$ The conference proceedings were contained in the journal World: for World Trade and World Law, no. I (winter 1955-56): 34 .

7 Preface to Einstein on Peace, ed. Otto Nathan and Heinz Norden (New York: Simon and Schuster, 1960), p. xv; Papers II: 59I.

8 The most extensive discussion, including quotations from the letter by Einstein, occurs in $B R A, 2: 7-\mathrm{IO}$. Nathan and Norden, in their comments on this campaign in Einstein on Peace, discuss Einstein's correspondence with John Dewey on the subject of contributing to the campaign (p. 425), but don't mention the less successful exchange of views with Russell. Clark discusses Russell's negative reaction, but only briefly (Clark, p. 522). He mentions the disagreement, with a quotation from Russell's letter concerning his wish to avoid the mistake of appeasement he had made in the late 1930s, in Einstein. the Life and Times (New York: World, 1971), p. 589. Ray Monk, in Vol. 2 of his biography of Russell, quotes Russell's letter to Einstein on the same point (Monk, 2: 300). 
a better understanding can be achieved of Russell's concept of pacifism, with respect both to its general principle of opposition to war and to exceptions it allowed for threats of force-and actual war-in order to prevent world war.

\section{RUSSELL AND EINSTEIN ON PACIFISM}

Russell noted that during the First World War both he and Einstein adopted an anti-war position. How Russell became a pacifist, based on a debate with the French logician Couturat during the Boer War some fifteen years earlier, has already been traced in a previous article in this journal.9 But I want to focus on the most interesting statement which Russell made, among the many papers and books he devoted to analyzing the causes of war and the need for peace, during this time. On 8-9 July 1915 the League for Peace and Freedom held a "Conference on Pacifist Philosophy of Life" at Caxton Hall, London. Russell's contribution, a paper entitled "The Philosophy of Pacifism", was printed as the first article in the volume containing the proceedings of the conference. Russell argued that not only was war evil, since it involved the wasteful destruction of life by hatred and violence, but also that its supposed goods - the valour of the combatant, the drama of the combat - were in fact frauds, using a Platonic argument that the victor was as debased by war as the vanquished. Russell called for passive resistance against invasion, pointing out that a people as well trained in the art of noncooperation with an invader as were soldiers in the technique of fighting the enemy, would soon frustrate the attempts by any invader to rule. But, in a final paragraph which was later cut, possibly by the publisher, when the article appeared as a separate pamphlet, Russell added:

Nevertheless, it is hardly to be expected that progress will come in this way, because the imaginative effort required is too great. It is much more likely that it will come, as the reign of law within the State has come, by the establishment of a central government of the world, able and willing to secure obedience by force, because the great majority of men will recognize that obedience is better than the present international anarchy. A central government of this kind will

9 David Blitz, "Bertrand Russell and the Boer War: from Imperialist to Anti-Imperialist", Russelh, n.s. I9 (1999): 6-28. command assent, not as a partisan, but as the representative of the interests of the whole. Very soon resistance to it would seem to be hopeless, and wars would cease. Force directed by a central authority is not open to the same abuse, or likely to cause the same long-drawn conflicts, as force exercised by quarrelling nations, each of which is the judge in its own cause. Although I firmly believe that the adoption of passive instead of active resistance would be good if a nation could be convinced of its goodness, yet it is rather to the ultigate creation of a strong central authority that I should look for the ending of war. But war will only end after a great labour has been performed in altering men's moral ideals, directing them to the good of all mankind and not only of the separate nations into which men happen to have been born. ${ }^{\text {Io }}$

Russell juxtaposes his ideal position-passive resistance to war based on love of humanity-to his practical position-the need for a coercive supra-national force to enforce peace. This theme of the necessity for world government in order to end war is one to which Einstein would also subscribe, along with the use of force by the international authority to prevent world wars.

Einstein, meanwhile, from the other side of the conflict-he had left neutral Switzerland in the spring of 19I4 to return to Germany just months before the German invasion of Belgium led to the British declaration of war-was also committed to peace, by both temperament and philosophy. In October 1914, a "Manifesto to the Civilized World", defending German militarism, was issued, with signatories including Ernst Häckel, Walter Röntgen, and Paul Ehrlich. A response was written by Georg Nicolai, a leading German pacifist, and entitled "Manifesto to Europeans". It was co-signed by Einstein, who thereby declared his position publicly. II Sixteen years were to pass before Russell and Einstein co-signed the same document.

In 1930 a manifesto calling for international disarmament was issued by the Women's International League for Peace and Freedom, following the ratification of the Kellogg-Briand Pact rejecting aggressive war. It was signed by Russell and Einstein, who agreed among others to the fol-

10 "The Philosophy of Pacifism" in Towards Ultimate Harmony: Report of Conference on Pacifist Philosophy of Life (London: Published for The League of Peace and Freedom by Headley Brothers, [1915]), p. I4; Papers 13: 154-5.

"For this and other references to manifestos co-signed by Russell and Einstein, see Einstein on Peace, Chaps. $1-7$ passim. 
lowing formulation: “... scientific methods of warfare have rendered national defence and protection of civilian populations illusory; a new war would mean simultaneous annihilation of a large part of the population by fire, poison gas and chemicals" (Einstein on Peace, p. ro5). The document was also signed by many other leading writers and scientists, including Thomas Mann and Ivan Pavlov.

That same year, both Russell and Einstein signed an appeal against conscription and the military training of youth, issued by the Joint Peace Council, a coalition including Quakers, the Fellowship of Reconciliation, the War Resisters' International, the WILPF (above) and others. It was also signed by John Dewey, Sigmund Freud, Thomas Mann and H. G. Wells, among others.

But in 1933 Einstein changed his position after the rise to power of the Nazis in his native Germany. Although requested to add his name in support of conscientious objectors in Belgium, he declined, and in a letter to the King - a personal friend-stated "in the present threatening situation, created by events in Germany, Belgium's armed forces can only be regarded as a means of defence, not an instrument of aggression" (ibid., p. 277). Russell, however, retained his pacifism relative to impending conflict. In Which Way to Peace?, published in 1936, he announced his unconditional support for the following policy, printed in all capital letters for emphasis:

TO ABSTAIN FROM FIGHTING, AND FROM ALL VOLUNTARY PARTICIPATION IN WAR BETWEEN CIVILIZED STATES; TO USE EVERY EFFORT TO PERSUADE OTHERS TO DO LIKEWISE; TO BRING ALL POSSIBLE INFLUENCE TO BEAR TO PREVENT THE PARTICIPATION OF HIS COUNTRY IN WAR; AND, WITHIN THE LIMITS OF HIS CAPACITY, TO AIM AT SIMILAR RESULTS IN OTHER COUNTRIES ALSO. ${ }^{\text {I2 }}$

Of particular importance is the reference to non-participation in wars "between civilized states". This is consistent with Russell's position during World War I, when he distinguished between four types of wars: "( $\mathrm{I}$ ) Wars of Colonization, (2) Wars of Principle, (3) Wars of Self-defence, and (4) Wars of Prestige."13 Although he recognized that wars of the

12 Which Way to Peace? (London: Michael Joseph, 1936), p. 224.

13 "The Ethics of War", Justice in War-Time (1915); Papers 13: 67. first type were "technically" unjustified because of the ruthlessness with which they were conducted, he admitted their retrospective value in so far as a new part of the world was opened to modern (western) civilization. These wars, Russell added, were a thing of the past. What he specifically objected to were wars between civilized states, that is to say, western industrialized states with advanced cultures, where the aim was prestige and the wresting of commercial and governmental advantages by force of arms: "Of these four kinds I should say that the first and second are fairly often justified; the third seldom, except as against an adversary of inferior civilization; and the fourth, which is the sort to which the present war belongs, never" (ibid.). The question of civilization plays a key role: wars which advance civilization are justified; those that do not are not.

Twenty years later, in 1936, Russell still saw the impending war in Europe as a war which could only lead to a vast decline in the level of civilization, and consequently he opposed it. His opposition in part was based on an exaggerated view-widely held at the time-that modern, scientifically based warfare would, within days of the outbreak of conflict, result in the devastation of cities and the annihilation of the civilization they supported. Based on this hypothesis, he felt that passive resistance was the only means to oppose aggression. This position was based on an evaluation, subsequently shown to be wrong, of the efficacy of aerial bombardment and the massive use of chemical weapons. Russell recognized that his argument was specific to the circumstances of the time, and was conditional rather than absolute:

The argument by which this conclusion has been reached has appealed only to common sense and common humanity, not to any abstract ethical principie; nor do I trouble to examine whether so drastic a policy is desirable at all times. I am concerned with the present time and the present prospect of disaster. To secure permanent peace will require great changes, economic as well as political, and the time for that will come if the present peril can be averted. But at this dangerous moment only an immediate policy can hope to succeed. (Which Way to Peace?, p. 234)

Russell added that this argument for opposition to the impending war was personal, rather than political:

The movement in favour of war resistance is not to be viewed primarily as 
political, but rather as a matter of personal conviction, like religion. It may spread fast enough to keep Great Britain neutral in the next war; if it does, we may hope, without excessive optimism, that it will afterwards, when the next war has given its terrible object-lesson, spread to the whole civilised world. It may, on the other hand, end in failure.

Thus, Russell's 1936 position could be termed "conditional personal pacifism", conditional because specific to the circumstances of the midI930s, and personal because based on strong personal feelings. It was this position Russell would reject in favour of "non-absolute political pacifism" once war with Nazi Germany had broken out and he had reversed his position on the nature of this conflict.

\section{WORLD WAR II AND RUSSELL'S RELATIVE POLITICAL PACIFISM}

It was only in 1940 that Russell publicly broached his change of position on the war, following the Nazi air war against England. By then Russell was living in the United States, to which he had moved with his family in search of employment just before the outbreak of conflict. During the first of two actions that deprived him of his livelihood-his disqualification from teaching at CCNY and his subsequent dismissal from his job as resident philosopher for the Barnes Foundation-Russell announced his support for the Allied cause. Russell's abjuring of a pacifist position on the war was motivated by love of country at a time when England was in an unfavourable circumstance: under air attack from Germany and threatened with invasion:

Ever since the war began, I have felt that I could no longer go on being a pacifist; but I have hesitated to say so, because of the responsibility involved. If I were young enough to fight myself, I should do so, but it is more difficult to urge others. Now, however, I feel that I ought to announce that I have changed my mind. ${ }^{14}$

In February of 1941, ten months before the us entered the fray, Russell returned to the topic in a lengthy letter to the editor of the New

${ }^{14}$ The New Statesman and Nation, n.s. 19 (8 June 1940): 719; Auto., 2: 233. This is an excerpt from a letter to Kingsley Martin dated 13 May 1940.
York Times. He stressed two points, one of principle, the other of practice. First, he noted that even in the First World War, he had not been a "complete" pacifist, admitting that some wars, such as the American War of Independence and the Civil War, were justified (as wars of principle). Secondly, he admitted that he had both overestimated the physical decimination that war would bring (especially the effects of aerial bombardment, which Britain had survived during the unfortunately termed "Blitz"), and had underestimated the bad effects of German occupation of non-German territories, especially the "appalling suffering and unbearable tyranny"ss produced by the Nazi juggernaut. Russell completed his letter with a criticism of President Hutchins of the University of Chicago, who argued, in ways Russell now rejected but earlier might have defended, that us participation in the war would do more harm than good. Nonetheless, Russell's role in support of the war, even after the Us entered the fray in 1942, was a minimal one, limited to a number of public declarations of support with few if any other engagements such as fund-raising, rallies or the like.

However, Russell did produce a significant document concerning his views, "The Future of Pacifism", in 1943. In it he distinguished between absolute and non-absolute pacifism, and between personal and political pacifism, arguing for a position he termed "relative political pacifism". ${ }^{6}$ This paper substantially clarifies, and provides a title (albeit a

is "Long-Time Advocate of Peace Approves Present War", New York Times, I6 Feb. 194I, sec. 4, p. 8. The title was provided by the Times, which subtitled the nearly pagelong letter: "Professor Bertrand Russell States Reasons for Changing Position, Disputes Stand of Dr. Hutchins and Hopes Ultimately for Federation of World".

${ }^{16}$ Russell's analysis of different forms of pacifism is one of many which have been made. Paul Weiss in a contemporaneous article identified five forms: the religious, the cynical, the sentimental, the political and the ethical. This latter was to combine all the positive elements which Weiss identified in the first four, excluding their errors and limitations. See Weiss, "The Ethics of Pacifism", Philosophical Review, SI (1942): 476-96. More recently, Martin Ceadel has renewed the distinction between "pacificism" and More recently, Martin Ceadel has renewed the distinction between pacificism and occasional support for a justified war, and the latter standing for unconditional rejection of all war. In these terms (also used by A. J. P. Taylor), Russell in 1936 defended a "pacifist" policy, and in 1943 a "pacificist" policy. See Ceadel, The Origins of War Prevention: the British Peace Movement and International Relations, 1730-1854 (Oxford: Clarendon P., 1996). Ceadel has discussed Russell's mid-1930s pacifism in Pacifism in Britain, I9141945: the Defining of a Faith (Oxford: Clarendon P., 1980). He developed his analysis of theories of war and peace, including militarism, crusading, defencism, along with 
slightly unwieldy one) for his preferred type of pacifism. By absolute pacifism, Russell understood "the doctrine that, in all circumstances, it is wrong to take human life-or even animal life, according to some." I7 Examples of defenders of this type of pacifism, which Russell viewed as largely motivated by religious considerations, were Tolstoy, Gandhi, the Quakers, and defenders of a literal reading of the Biblical injunction, "Thou shalt not kill".

"Relative pacifism" was defined as "the doctrine that very few wars are worth fighting, and that the evils of war are almost always greater than they seem to excited populations at the moment when war breaks out" (p. 8, italics in the original). Two further distinctions rounded out Russell's framework for his defence of relative (or non-absolute) political pacifism. Individual pacifism focuses its adherents on their personal duty to refuse participation in war, whereas political pacifism concentrates energies and efforts on preventing governments from going to war. An individual pacifist may not be a political pacifist, supposing that he or she is motivated by religious beliefs but eschews political action. Similarly, a political pacifist need not necessarily be an individual pacifist, as in the case where an opponent of war acquiesces in participation once the war breaks out. Russell's preference was for relative, political pacifism:

I think myself that the most useful kind of pacifism, and also the one most likely to become influential, is relative political pacifism. According to this view, there are causes, but only a very few, for which it is worth while to fight; but whatever the cause, and however justifiable the war, war brings about such great evils that it is of immense importance to find ways short of war in which the things worth fighting for can be secured. I think it is worth while to prevent England or America being conquered by the Nazis, but it would be far better if this end could be secured without war. (Pp. 8-9; italics added)

Russell's form of non-absolute pacifism was more than a philosophy of peace in the narrow sense. It was a philosophy of peace and war, with

pacificism and pacifism, in Thinking about War and Peace (Oxford: Clarendon P., 1987). For extensive discussion of the history of peace movements in Europe and America, see Peter Brock's works, including Varieties of Pacifism: a Survey from Antiquity to the Outset of the Twentieth Century, $4^{\text {th }}$ ed. (Toronto: U. of Toronto P., 1998), and Pacifism in the Twentieth Century with Nigel Young (Syracuse: Syracuse U. P., 1999).

${ }_{17}$ "The Future of Pacifism", American Scholar, 13 (winter 1943-44): 7-13. predominance given to the former, but not excluding the latter under special circumstances. It had the advantage of not being based on religious considerations of a transcendental nature, but on an analysis of the concrete circumstances surrounding the outbreak of any war.

\section{EINSTEIN, WORLD WAR II AND "DEDICATED" OR} "DETERMINED" PACIFISM

Einstein's role with respect to World War II was somewhat different from that of Russell, both in terms of the onset of his support for war preparation (1933) and his influence on the course of war armament (after 1939). As is well known, Einstein wrote a letter in 1939 urging President Roosevelt to proceed with the study of uranium as a potential weapon of war. He began: "Some recent work by E. Fermi and L. Szilard, which has been communicated to me in manuscript, leads me to expect that the element uranium may be turned into a new and important source of energy in the immediate future" (Einstein on Peace, p. 294), and continued: "In the course of the last four months it has been made probable-through the work of Joliot in France as well as Fermi and Szilard in America-that it may become possible to set up nuclear chain reactions in a large mass of uranium, by which vast amounts of power and large quantities of new radium-like elements would be generated" (p. 295). Ominously, he warned: "This new phenomenon would also lead to the construction of bombs, and it is conceivable-though much less certain-that extremely powerful bombs of a new type may thus be constructed. A single bomb of this type, carried by boat or exploded in a port, might very well destroy the whole port together with some of the surrounding territory" (ibid.).

However, Einstein's knowledge of the means to construct such a weapon-to which task the energy of others, including Szilard, Oppenheimer and Teller would be focused-was limited, and he added: "However, such bombs might very well prove to be too heavy for transportation by air" (ibid.). Alas, as the people of Hiroshima and Nagasaki were to discover, this was not the case.

Einstein had no further role in the development of the bomb. However, he was to write another letter to Roosevelt, on 5 March 1945, received only after the President's death, which was his first effort to stop the deployment of the very bomb which he had recommended for devel- 
opment in his r939 letter. The letter was an introduction for Leo Szilard, then leading the campaign to oppose the use of the A-bomb on Japan, and, in a roundabout way, attempted to indicate to the President that a major problem had developed: "I understand that he [Szilard] now is greatly concerned about the lack of adequate contact between scientists who are doing this work and those members of your Cabinet who are responsible for formulating policy" (ibid., p. 305). What had changed?

The change was the defeat of Nazi Germany that spring. Central European scientists such as Leo Szilard-a Hungarian forced into exile by the Nazi conquest of his homeland-had naturally focused their attention and anger at Hitler and the Nazi regime. Once that regime was defeated, they were less inclined to use maximal force (the atom bomb) on the remaining Axis power. To the contrary, many (though not all) of the American scientists, while angered by the Nazi atrocities, were also (and even more) enraged by the Japanese attack on Pearl Harbor, immortalized as that "day of infamy" for which punishment and revenge were sought. ${ }^{18}$

Moreover the group opposing the use of atomic weapons on Japan felt that it was fair to develop an atomic bomb against the Germans, since these latter had a similar project headed by Werner Heisenberg, the discoverer of the uncertainty principle in quantum mechanics. But the Japanese, though they had well qualified physicists such as Hideki Yukawa-a Nobel prizewinner for work on particle theory-had no atom bomb project (though they did use biological and chemical warfare in China). By this somewhat simplistic tit-for-tat reasoning, it was unfair to use the A-bomb against Japan, at least without a test to demonstrate its power to the Japanese and persuade them to capitulate before its use against civilian targets. This was not to be the case, and we know that the United States used A-bombs on both Hiroshima and Nagasaki in early August of 1945 .

Einstein most clearly stated his theoretical position on pacifism in a letter of 1953 replying to the Japanese pacifist Seiei Shinohara. Shinohara

${ }^{18}$ See Gregg Herken, The Winning Weapon: the Atomic Bomb and the Cold War, 1945-50 (New York: Knopf, 1980); Martin J. Sherwin, A World Destroyed: Hiroshima and the Origins of the Arms Race (New York: Vintage Books, 1987) for analysis of debates during this period among scientists and politicians. See William Lanouette (with Bela Szilard), Genius in the Shadows (New York: Charles Scribner, 1992) for Szilard's role. referred to an article by Einstein that appeared in the journal Kaizo, and inquired how, as a pacifist, Einstein could have written the letter he did write to Roosevelt, encouraging the development of the atomic bomb. Einstein responded, making the important distinction between an absolute and a convinced pacifist:

Your reproach is well taken from the viewpoint of an absolute, i.e., unconditional pacifist. But in my letter to Kaizo I did not say that I was an absolute pacifist, but, rather, that I had always been a convinced pacifist. While I am a convinced pacifist, there are circumstances in which I believe the use of force is appropriate-namely, in the face of an enemy unconditionally bent on destroying me and my people. In all other cases I believe it is wrong and pernicious to use force in settling conflicts among nations. (Einstein to Shinohara, 22 Feb. I953; Einstein on Peace, pp. 585-8)

Einstein elaborated on the matter in a second note to Shinohara: "I am a dedicated [entschiedener] but not an absolute pacifist; this means that I am opposed to the use of force under any circumstances, except when confronted by an enemy who pursues the destruction of life as an end in itself" (23 June 1953; ibid., p. 589). The distinction between absolute pacifism on the one hand, and convinced or dedicated pacifism on the other, deals not with the rule of pacifism-oppose war-but with the existence of an exception to the rule. This exception admits war for the purposes of self-defence against an enemy who would otherwise destroy whole peoples (as in the Nazi genocide against the Jews); that is to say, as Einstein put it, an enemy whose principle is the "destruction of life as an end in itself". The case of the Japanese in World War II was different from that of the Nazis, despite the war crimes of the former in their fight for control over Asia. Einstein continued: "I have always condemned the use of the atomic bomb against Japan. However, I was completely powerless to prevent the fateful decision for which I am as little responsible as you are for the deeds of the Japanese in Korea and China" (ibid.).

The distinction drawn by Einstein between absolute pacifism - which brooked no exceptions to its rule of opposition to all wars-and convinced or dedicated pacifism-which allowed an exception for war against those who practise genocide and oppose life as such-is similar to Russell's form of relative political pacifism. Both were non-absolute, allowing for exceptions to the rule of opposing war when specific conditions were realized. Russell, during the mid- to late 1940s, believed that 
Soviet possession of the A-bomb would lead to a world war that would end civilization. Thus he was willing to recommend the threat of war, and even to entertain the notion of a preventive war, against the Soviet Union. This was the basis for his 1947 disagreement with Einstein.

\section{THE 1947 DISAGREEMENT}

The effect on Einstein of the use of atom bombs on civilian targets was to more fully turn his attention to the struggle against nuclear weapons. The Emergency Committee of Atomic Scientists was established in 1946 by leading physicists who opposed further development of atomic arms, with Einstein as chairman. The Committee supported the publication of the Bulletin of the Atomic Scientists. ${ }^{19}$ It was as chairman of the Emergency Committee of Atomic Scientists that Einstein sent out a form letter soliciting funds, addressed to "Dear Friend" and dated 22 April 1947. Einstein began with words with which Russell would ordinarily have agreed, warning of the danger of this new power in the hands of "outmoded nationalisms":

Through the release of atomic energy, our generation has brought into the world the most revolutionary force since prehistoric man's discovery of fire. This basic power of the universe cannot be fitted into the outmoded concept of narrow nationalisms. For there is no secret and there is no defense; there is no possibility of control except through the aroused understanding and insistence of the peoples of the world. ${ }^{20}$

Einstein continued with a simple appeal for a financial contribution

r9 The Bulletin was initially published by the Atomic Scientists of Chicago, which fused with the Committee of Concerned Atomic Scientists in 1948. The list of sponsors included Hans Bethe, A. H. Compton, James Franck, Samuel Goudsmit, Hans Muller, J. Robert Oppenheimer, Linus Pauling, I. I. Rabi, Julian Schwinger, Leo Szilard, Harold Urey, Victor Weisskopf, and Sewall Wright. It even included, though not for long, Edward Teller, whose unconditional support for the development of the H-bomb brought him into sharp conflict with Einstein and Russell. The sponsors were mainly, though not exclusively, nuclear physicists; biologists such as Muller and Wright were included, as were chemists such as Franck and Urey.

${ }^{20}$ Einstein, letter of 22 April 1947 (RAI 710.049700). Einstein was chairman of the Emergency Committee, with Urey as vice-chairman, along with Bethe, T. R. Hogness, Philip M. Morse, Pauling, Szilard and Weisskopf as trustees. towards a $\$ 1,000,000$ objective for an educational campaign on the dangers of nuclear weapons, an appeal which Russell would ultimately reject because the Soviet Union had declined the recent proposal by the us for international control of nuclear energy (usually referred to as the Baruch proposal). Baruch submitted his proposal to the first session of the UN Commission on Atomic Energy on 133 June 1946. It followed on a Us report mandated by Secretary of State Dean Acheson and prepared by a commission headed by David Lilienthal, chairman of the Tennessee Valley Authority (TVA) and later chairman of the us Atomic Energy Commission (AEC). The Baruch proposal adopted the basic idea of international control of the sources of atomic energy from the Lilienthal-Acheson plan, and added measures for enforcement of that control, including the abolition of the veto by any country in matters concerning uranium production and uses. It was this latter item, underscoring the urgency and importance of international control of a real sort, which both attracted Russell and repulsed the Russians. Russell saw it as the first step to international government and a supra-national monopoly of nuclear weapons, while the Soviets saw it as an American ploy to undermine the state sovereignty of their Communist regime. ${ }^{2 \mathrm{I}}$

The following words, from Baruch, could well have been written by Russell, who would express himself in rather similar terms in his later declarations of the choice between "a new Paradise ... or universal death" (as in "Man's Peril", 1954). Baruch opened his declaration thus:

My fellow members of the United Nations Atomic Energy Commission, and my fellow citizens of the world. We are here to make a choice between the quick and the dead. That is our business.

Behind the black portent of the new atomic age lies a hope which, seized upon with faith, can work our salvation. If we fail, then we have damned every man to be the slave of Fear. Let us not deceive ourselves: We must elect World Peace or World Destruction. ${ }^{22}$

${ }^{21}$ See International Contral of Atomic Energy: Growth of a Policy (An Informal Summary Record of the Official Declarations and Proposals Relating to the International Control of Atomic Energy Made Between August 6, 1945 and October 15, 1946) (Department of State; Washington, DC: Us Government Printing Office, 1946) for us positions. See Joseph L. Nogee, Soviet Policy towards International Control of Atomic Energy (Notre Dame, Ind.: U. of Notre Dame P., 196r) for an analysis of Soviet positions.

${ }^{22}$ Bernard Baruch, "The American Proposal for International Control", Bulletin of 
It is not hard to see how Russell resonated to the Baruch proposal, and fully endorsed it.

Just days after receiving Einstein's form letter, Russell on 30 April made a statement in the House of Lords on the problem of atomic energy which was reprinted, with omissions, in the Bulletin of the Atomic Scientists. Russell called once more for an international control of atomic energy, ultimately leading to a world government with no veto for any member. He rejected the Soviet argument limiting inspection to agreedupon sites, and concluded with the following pessimistic analysis:

If only the Russians could see it in that light [as an international question, not a national one] we might be able to get some agreement with them, but I have very grave doubts as to whether it will be possible. In the absence of that, I think the question will arise as to what degree of coercion it would be right and proper to apply."23 (Parenthetical clarification added)

Russell continued in the same vein in an essay entitled "Still Time for Good Sense", ${ }^{24}$ which Einstein read and to which he responded with a letter sent on 19 November 1947. In his article Russell pointed out that science had removed the limitations that had hitherto existed on the destructiveness in wars: "The human race, consequently, is faced with a new situation: It must alter its political habits or perish" (p. 56). As he had so often argued, Russell noted that the ultimate safeguard against mass destruction due to world war was a world government which maintained a monopoly of the major weapons, including atomic bombs and the means to deliver them. This international government should be charged with the sole task of maintaining world peace, and would be

the Atomic Scientists, 2 (July 1946): 3-5, 10.

23 "Atomic Energy Control", Parliamentary Debates (Lords), (5), I47 (30 April 1947): cols. 272-6; with omissions, in "The House of Lords Debates the Control of Atomic Energy", Bulletin of the Atomic Scientists, 3 (July 1947): 184-5.

${ }^{24}$ In '47, Magazine of the Year (New York), 1, no. 9 (Nov. 1947): 56-63. Robert Schulmann, coeditor of the Einstein Papers Project at Boston University, indicates in his e-mail to me of 8 February 2000 that it was this paper that Einstein referred to in his letter of 19 November. The photocopy of Einstein's typed copy of this letter in the Russell Archives (REC. ACQ. 257, from the Einstein Archives) is dated is November, but Russell, in his letter of 24 November, responds to one dated 19 November. Schulmann indicates that a note by Helen Dukas, Einstein's secretary, corrects the date of the original to 19 November and indicates "letter mailed as dated Nov. 19th, 47 ". See also n. 25 . allowed to intervene only to prevent individual governments from engaging in aggression, defined as "any act of war not sanctioned by the international authority" (p. 57). Significantly, Russell identified the Lilienthal plan and the Baruch proposal for an international agency to control nuclear energy as an "enormously important first step" (p. 59) towards a world government, and he reacted strongly to the Soviet Union's rejection of the plan, which its leadership considered a threat to their state sovereignty. Russell drew an ominous conclusion:

However reluctantly, I have been driven to the conclusion that the Soviet Government foresees within a few years a situation in which it could win an atomic war. We may therefore expect its policy, if the West permits, to be one of temporizing until that time comes, while refusing steadfastly to agree to any plan which would make an atomic war impossible. (P. 58)

In his letter of 19 November 1947 about this article, Einstein referred to a number of points of disagreement, with each lettered comment referring to a part of Russell's article which Einstein had referenced by underlining and affixing the letter corresponding to each point of critique. Einstein's copy of Russell's article, recently discovered in the Russell Archives, allows for the first time for a detailed reconstruction of their disagreement. Einstein began by referring to Russell's "brilliant article" for "world government propaganda", and went on to propose that if Russell would make a series of suggested changes, the article would be reprinted as a separate pamphlet by the Emergency Committee of Atomic Scientists. "Don't be angry with me for my comments" he noted, and then indicated in a series of lettered comments A-F the points of disagreement he had, and suggestions for changes. Einstein's comments $\mathrm{A}-\mathrm{F}$, and the corresponding passages from Russell's article, are reproduced as an appendix to this article. ${ }^{25}$

${ }^{25}$ The translation from Einstein's German came with the photocopied letter from the Einstein Archives. The translation excludes the introductory paragraphs. I wish to thank Martha Wallach and Stuart Barnett of the Central Connecticut State University Modern Language and English departments, respectively, for providing translations of the missing sections and improvements to the existing translation.

The pages of Russell's article with Einstein's guide letters A-E, but missing the page with the annotation F, were found in the Russell Archives. They were among two detached partial tear-sheets of the article in the B\&R C47.I2 file containing L. E. 
Although Einstein admitted that the Lilienthal-Baruch plan was "sensible" and "carefully worked out", one which should have received a better reception from Russia, he continued that "it was very difficult for the Russians to agree to the plan" because it was asymmetric as to demands placed on the Soviets and on the Americans, and because of Russian fears of Western presence in their country:

First of all, it assumed that the demands it envisaged should be met immediately, whereas the formulation of methods and delivery of bomb piles were to be postponed to a time deemed suitable in the judgment of the United States. Secondly, the Russians undoubtedly fear that inspection of such wide scope, and in general the presence in their country of so many "westerners", would be a threat to Russia's inner balance. (Comment A)

More seriously, Einstein was concerned with what he took to be Russell's claim "according to which Russia's refusal must be considered as motivated by her intention of undertaking an aggressive war at some later date." Einstein warned that "Publication of such a paragraph [by the Committee] would necessarily increase the danger of preventive war, which already haunts many people here" (comment B, parenthetical clarification added).

Einstein was also dubious about Russell's desire for an American-led alliance to force the USSR to accept international supervision of nuclear energy. Although Einstein reiterated his support for world government, he did not believe that the supervisory personnel proposed in the Baruch-Lilienthal plan could form a nucleus for it (comments C-F) ${ }^{26}$

Denonn's complete tear-sheets. Einstein had removed the pages from the journal, affixed his guide letters in blue fountain-pen ink, and sent the detached pages along with his explanatory letter to Russell. That the letters are clearly Einstein's is indicated by the unmistakable way in which he formed the " $E$ ", exactly the same as the way in which he signed his surname. The pages with Einstein's letters remained mixed up and unnoticed in the file until I identified them while preparing this article; at some time they had become separated from his letter, which, like most of Russell's correspondence from the I940s, never reached McMaster. The letter is not listed in Feinberg's catalogue, nor does it appear on the RA microfilm made in 1968-69.

${ }^{26}$ Einstein also drew two un-lettered marginal lines in sections of Russell's article, both by the first column on p. 62. In the first Russell approvingly mentions United States leadership for world peace, and in the second he refers to France's "archaistic" fear of Germany. As we know, Einstein was dubious about us leadership and concerned about Germany, so these marginal lines likely indicate specific points of disagreement.
Russell's response was dated 24 November. He began: "I wish with all my heart that I could agree to the alterations you suggest". But he could not, for he held Einstein's views on the USSR to "spring from an opinion different from mine". Russell, unwilling to repeat his mistaken underestimation of Nazi Germany before the Second World War, now rejected what he believed to be a new appeasement, this time of the USSR. He specifically responded to Einstein's first three lettered criticismsdealing with the Lilienthal-Baruch proposals, Soviet war intentions, and American world leadership-as follows:

I think the only hope for peace (and that a slender one) lies in frightening Russia. I favoured appeasement before 1939, wrongly, as I now think; I do not want to repeat the same mistake.

In particular:

A. I only advocated "some such scheme" as that of the Lilienthal Report; I should be glad to see any emendation that did not make it ineffective, but inspection is essential.

B. I did not say that Russia is preparing an aggressive war; what I said implied rather that Russia expects to have to wage a defensive war. The line of action is the same in either case.

C. I think it essential that America should assume leadership; without a leader nothing gets done, and without $\mathrm{u} . \mathrm{s}$. leadership all minor Powers will be too frightened to do anything.

Russell concluded the letter with a pessimistic evaluation of the prospects of influencing the USSR to a more reasoned position through conciliation, a view, he noted, which he had held since his visit in 1920 :

Generally: I think it useless to make any attempt whatever to conciliate Russia. The hope of achieving anything by this method seems to me "wishful thinking".

I came to my present view of the Soviet Government when I went to Russian in 1920; all that has happened since had made me feel more certain that I was right.

As a result of the foregoing, Russell declined to contribute to the Emergency Committee campaign, despite his admiration for the work in general: "The work of the Atomic Scientists of America seems to me most admirable, and I am the more sorry that I cannot collaborate in this matter" (ibid.). 


\section{RUSSELL AND THE THREAT OF WAR AGAINST THE USSR}

Russell's rejection of Einstein's overture was closely related to the antiSoviet position Russell held from 1945 to 1950 . This in turn was related to his consideration of the use of a threat of war to contain the Soviet Union with respect to its ambitions in Western Europe, and to force it into international agreements to control atomic energy. While still arguing for peace through world government, Russell had allied himself with the anti-Communist right, including the New Commonwealth movement, headed by Winston Churchill. The New Commonwealth shared Russell's commitment to world government and united a wide spectrum of liberal and conservative backers of an international authority. Russell's anti-Communism was not new: he had been a severe critic of Marxism from the I 890 os on, when he observed and rejected the views of the German social democrats. His visit to the Soviet Union convinced him that Communism was antagonistic to the individual and intellectual liberties that he cherished. The Stalin period in the Uss R reinforced his view of Communism as a threat to individual liberty and liberal temperament.

Russell made his position most succinctly in a series of numbered theses concluding his 1947 pamphlet, Towards World Government, the content of which was also delivered on behalf of the New Commonwealth as lectures in Holland and Belgium in the autumn of 1947. Because this public statement of his views was systematic, in ways in which more journalistic articles were not, and because it appeared in the same year as Russell's disagreement with Einstein, it is worth analyzing in some detail. The conclusion set out Russell's view thus:

The argument that I have been developing is as simple and as unescapable as a mathematical demonstration. I will summarize it in the following proposition:

x. Mankind cannot long survive, in this age of scientific warfare, unless great wars can be prevented.

2. The only way to prevent great wars is to create a single government possessing a monopoly of the more formidable weapons.

3. The first step in this direction-for which governments and public opinion are ready in most parts of the world-is the creation of an international authority for the control of atomic energy.

4. This step has been advocated by the United States and resisted by Russia.

5. If Russian resistance can be overcome by diplomatic pressure, full international government may come peacefully by gradual degrees.

6. Diplomatic pressure is more likely to succeed if many nations join in it than if it is left to the United States.

7. If diplomatic pressure fails, war, sooner or later, is inevitable.

8. If there is war, it will be less destructive if it comes soon than if it comes late, and if many nations support the United States than if few do so.

9. If there is war, the main issue should be the creation of an international government; and if this is its outcome, the next war may be the last.

Io. If peace can be made secure, there is every reason to expect that mankind will be happier than ever before; if not, unhappier.

This momentous issue is to be decided during the next few years by the collective will of mankind. No issue of equal importance has faced our species since it emerged from the ape. ${ }^{27}$

The numbered statements constitute a theory, not merely an enumeration of separate beliefs. Note that the first four are positive statements, either of basic assumptions or axioms (points $1-3$ ) or of important matters of fact (pt. 4). The remaining points $(5-10)$ are all formulated as hypotheticals, dealing with possibilities for the future should specified conditions occur or fail to occur. Like any empirical theory, the basic assumptions are themselves not empirical, as Russell recognized in his philosophical writings about axiom systems. But they must pass the logical tests of consistency, independence and comprehensiveness. The three axioms deal with the tendency of scientific advance to make warfare more deadly (a general historical claim), the need for a world government with a monopoly of the major means of destruction (a longheld axiom of his political thought), and the need to control nuclear energy through an international authority (a transitional measure to world government). They are clearly mutually consistent and independent of each other and provide a sufficient basis so that what follows-specific conditional statements about Russia, the West, the A-bomb and the threat of war-can be taken as conclusions drawn from them.

The key fact, which marks the transition from basic assumptions to specific conclusions, was the Baruch proposal for the international control of atomic energy (pt. 5). This set the stage for a series of conclusions, formulated as hypotheticals, given their reference to future events. Russell stated the need for diplomatic pressure on Russia (pt. 6), the

27 Towards World Government (London: New Commonwealth, 1947), Pp. II-12. Technically, humans are "co-descended" with the great apes from a common progenitor or ancestral species. This is what Russell likely meant by the use of the term "emerged". 
failure of which would lead to war (pt. 7). Such a war would be less destructive if it occurred earlier rather than later (pt. 8). If war against Russia were to occur and its outcome were to be the creation of a world government, then this would suffice to end war (pt. 9). The diplomatic pressure (pt. 7) was clearly intended to be a threat of war unless the Soviet Union accepted international control of atomic energy. ${ }^{28}$ Russell concluded with the choice between world peace and the happiness of mankind, or further unhappiness through unending war (pt. 10). This question of war and peace, Russell held, was the key issue for humanity.

This was all the more true for Russell once the Lilienthal report had been given real force by the Baruch proposal, which Russell, but not Einstein, saw as the embryo of a world government, with all the moral legitimacy that entails. A further difference between Russell and Einstein was the problem of Germany. Russell saw Soviet mistreatment of the German population in its zone of control as equivalent to Nazi atrocities during World War II. Speaking in December 1945 in the House of Lords in a debate over Central Europe, Russell focused on the problem of hunger in Germany as a result of Communist policy, and said: "The Russians, and the Poles with Russian encouragement have, I regret to say, adopted a policy of vengeance, and have so far as I am able to discover, committed atrocities very much on the same scale and of the same magnitude as those of which the Nazis were guilty." 29 In a series of articles and letters to the editor, Russell continued to campaign for better treatment of German civilians and to protest Soviet mistreatment. ${ }^{30}$

Einstein, on the other hand, advocated the theory of collective guilt, placing a heavy burden of blame on the German people for their support of the aims and methods of the Nazis. In 1948, Einstein refused the offer of honorary membership in the German Association for World Govern-

28 The question whether Russell advocated preventive war is a controversial one, and has been the subject of a discussion in Russell involving Douglas P. Lackey and Ray Perkins, Jr. See Lackey, "Russell's Contribution to the Study of Nuclear Weapons Policy", Russell, n.s. 4 (1984): 243-52; Perkins, "Bertrand Russell and Preventive War", n.s. I4 (1994): I35-53; Lackey, "Reply to Perkins on "Conditional Preventive War'", n.s. I6 (1996): 85-8; and Perkins, "Response to Lackey on 'Conditional Preventive War'", n.s. I6 (1996): 169-70. An evaluation of this controversy requires an article of its own.

29 "Situation in Central Europe", Parliamentary Debates (Lords), (5), 138 (5 Dec. 1945): col. 376 .

${ }^{\circ}$ See, e.g., his letters to the editor of The Times, 23 Oct. 1945 and 15 April 1947. ment, and in 1949 he declined to become a foreign scientific member of the newly reorganized Max Planck Institute; this pattern of rejection of honours and memberships from German institutions continued for the rest of Einstein's life. The following comment made in r950 is indicative of his stance, which was far more sympathetic to the Soviet Union than Russell's, and far less understanding of Germany and the Germans:

If a serious attempt were made, I see no reason why it should not be possible to reach an agreement with Soviet Russia; the Soviet Union has nothing to gain from an armed conflict and, no doubt, wants to maintain peace. The Germans, however, with their rigid mentality, know no alternative but to fish in muddy waters, taking skillful advantage of the discord they have fostered between the United States and Soviet Russia. (Einstein on Peace, p. 524)

Russell's analysis of the international situation was just the opposite: Germany, rather than playing a divisive role by creating conflict between the US and USSR, was the victim of division at the hands of the aggressive Russians. Russell had, as noted above, defined aggression as "any act of war not sanctioned by the international authority". By definition, the threat of war, indeed, even the act of war, of the Us-led alliance against the USSR would not fall under the rubric of aggression, so long as it was intended to force the Soviet Union to accept international control of atomic energy and prevent any possible nuclear world war. Russell's statements on Russia at this time- - even his most extreme ones in private letters which did advocate war (something he never argued for in public without appropriate qualifying conditionals) —are indeed consistent, not inconsistent, with his stated view of relative political pacifism. ${ }^{3 \mathrm{I}}$

\section{RENEWAL OF THE EINSTEIN-RUSSELL COLLABORATION}

Russell's shift in 1954-55 to advocating a campaign against nuclear world war directed at both the us and the USSR, was due to a change in his

${ }^{31}$ It remains to analyze the language used in Russell's private letters, especially those to his friends Gamel and Gerald Brenan (frequent correspondents during the period 1945-50), and the content of the letter he wrote to Walter Marseille on 5 May 1948, which was a key document used in the I950s to argue that Russell had "advocated" preventive nuclear war against the USSR. However, these were private letters containing expressions of personal feelings, rather than public statements of intended policy. 
thinking brought about by changes in the international arena. Russell's antagonism towards the Soviet Union, and his related threats and considerations of war with respect to it, continued through 1950, as the articles from that year indicate. ${ }^{32}$ But evidence began to accumulate of Russia's non-aggressive stance towards Western Europe and its disinclination, despite harassing acts by itself and its satellites, to provoke a world war. By May of 1949, the Berlin crisis had all but been resolved. The UssR, rather than provoking armed conflict, instead backed down, eventually allowing resupply of the city by normal routes (though the airlift continued for some time to build up a stock for any future crisis). Russell himself had gone to Berlin at the request of British authorities during the blockade to bolster the population's resistance to the Russians. The Soviet Union had certainly "misbehaved" in blockading West Berlin; but unlike Russell's hypothetical scenario of the time, the action did not escalate the matter into war with the West.

The Korean War, which began in June 1950, pitted Soviet allies (North Korea, eventually aided by China) against a Western coalition (under the umbrella of the United Nations) led by the Us and including Britain and Canada. Still, there was no indication of Soviet intent to attack Western Europe, and it was there that Russell's main concern lay. Nor did the conflict escalate into a world war or threaten to do so, at least not on the Communist side. If anything, it was General MacArthur, subsequently dismissed by Truman, who favoured escalation of the war to China, and it was he who provoked and was surprised by the Chinese "volunteers" who joined the conflict. By the end of the Korean War in July 1953, the Soviet threat seemed to recede just as in the United States right-wing anti-Communism, led by Senator Joseph McCarthy, was on the upswing. Russell followed with evident disapproval this campaign, from McCarthy's declaration that hundreds of Communists were active in the Us state department (February 1950) to his downfall during the hearings over his charges of Communist infiltration in the army (April 1954). In particular, it was concern over McCarthyism which led to a letter from Einstein to Russell. Russell, in a letter to the editor, "Obeying Law in Testifying", 33 defended Einstein, who was under

${ }^{32}$ For example, "The Next Fifty Years", European Affairs, I, no. I (Jan. 1950): 5-7; "Is a Third World War Inevitable?", United Nations World, 4, no. 3 (March 1950): 1I-13.

${ }^{33}$ The New York Times, 26 June 1953, p. 18; Einstein on Peace, p. 550; BRA, 2: 60-1. attack for advocating resistance to loyalty oaths. Einstein replied personally on 28 June:

With your fine letter to the N.Y. Times you have performed a good service for the good cause. The intellectuals here right down to the youngest students are completely overawed. Apart from you, hardly a single "prominent figure" has declared himself energetically for the fight against the mischief being wrought by the politicians. They feel so strong because they have successfully persuaded the masses that the Russians, and the Communists in this country, have endangered the fatherland. The further they carry this, the surer they feel of being re-elected by the misguided crowd. Linked with this is the fact that Eisenhower did not dare to reprieve the two Rosenbergs, even though he knows very well how much this execution has damaged America's image abroad.

(RAI 710.04970I; another trans. in Einstein on Peace, pp. 550-I, Auto., 3: 59)

At the international level significant changes occurred when the USSR exploded its first atomic bomb in August 1949, and the us pushed forward with the development of the hydrogen bomb. By the mid-r95os both superpowers were armed with sufficient nuclear bombs to devastate each other and the world. As Russell later noted in his Autobiography, he was still a fervent anti-Communist at the time of the Berlin blockade, but his views changed thereafter:

Later I was brought around to being more favourable to Communism by the death of Stalin in 1953 and by the Bikini test in 1954; and I came gradually to attribute, more and more, the danger of nuclear war to the West, to the United States of America, and less to Russia. This change was supported by developments inside the United States, such as McCarthyism and the restriction of civil liberties. (Auto., 3: 20)

Russell therefore shifted his position and began to advocate the organization of a campaign for nuclear disarmament and world peace, marked most dramatically by his talk "Man's Peril" on Christmas eve, I954. It was this choice to combat the danger of atomic world war due to the arms race between the two superpowers which led to the RussellEinstein statement of 1955 . The response to Russell's broadcast was immediate and massive, with correspondents ranging from Lord Rothschild to Charles Marland, a Quaker, and E. M. Johnston, an individual associated with Communist groups, proposing that the talk be reprinted as a pamphlet. Russell received letters from the German physicist Max Born 
(on 2I January) and the French chemist F. Joliot-Curie (on 3I January). Both of them were influenced by Russell's 23 December talk and each suggested a scientists' campaign against the "peril to mankind" Russell had so eloquently identified. Russell contacted leading scientists and Nobel laureates, beginning with Einstein first and foremost, to whom he wrote on Ir February. Einstein responded warmly, and the RussellEinstein statement announced to the world on 9 July was the result. ${ }^{34}$

The path leading to the 1955 Russell-Einstein cooperation was a complicated one for two individuals sharing a basic viewpoint. Both were, in Einstein's terms, "convinced" or "dedicated", but not "absolute" pacifists (or non-absolute, "relative political" pacifists, to use Russell's term). While opposition to war was the basic rule, exceptions were allowed in the case of a power determined to wage war in order to destroy peoples and their culture (genocide in the case of a single people, or omnicide in the case of mass destruction on a global scale).

Russell still held to the pacifist rule in the late 1930s when Einstein invoked the exception proviso in the aftermath of the Nazi rise to power, in order to support armed resistance to the Nazis who threatened "enemy" peoples with extinction. Subsequently, in the late r940s, it was Russell who invoked the exception proviso, since he had come to believe that Soviet Russia posed a danger to the survival of Western civilization and all of humanity. Einstein, meanwhile, maintained the pacifist rule and held out hope for peaceful coexistence between the US and USSR. These differences were important, but not fundamental.

Both Russell and Einstein were thinkers who based their philosophies on logic and science, the former providing an à priori and rationalist foundation to their views, and the latter an empirical and à posteriori framework. It was this combination of rationalism and empiricism, of strongly held principles and flexible applications to changing circumstances, which accounts for the complex nature of their brand of pacifism. It is in this light that Russell's changing positions can be understood, reflecting as they did his understanding of changing circumstances and the consequent need to determine on a case by case basis the application of either the pacifist rule or the exception proviso. This allowed Einstein to recognize that his disagreement with Russell was

34 The exchange is in Einstein on Peace, pp. 624-31.

about specific circumstances and not one of general principle. When changed circumstances led both to agree that the main danger was now the arms race between the two superpowers, each armed with sufficient H-bombs to destroy world civilization, the conditions were united for a renewed collaboration between Russell and Einstein. Because of their shared philosophy of war and peace, cooperation was easy to re-establish, and their final interaction was both gracious and genuine.

\section{APPENDIX: EINSTEIN'S COMMENTS ON RUSSELL'S ARTICLE}

Italicized words in Russell's text correspond to the sentence or part of a sentence with a vertical line in the margin, along with a corresponding letter, in Einstein's copy. A word in Russell's text printed here in small capitals was underlined by Einstein.

"C" appears twice on the same page, first before text at the bottom of a left-hand column, and second at the beginning of the next paragraph in the right-hand column. "leadership" in Einstein's comment $\mathrm{C}$ is underlined in the translation in BRA though not in the German typescript.

The page of Einstein's copy of Russell's article with the paragraph referred to by the letter $\mathrm{F}$ is not preserved; the paragraph indicated in the column "Russell's text" is the first paragraph following that referred to by the letter $\mathrm{E}$ which mentions the Baruch plan in relation to world government.

\section{EINSTEIN'S RUSSELL'S TEXT} LETTER

In the movement to bring atomic energy under international control, America has shown an initiative which is specially honourable in view of America's temporary monopoly. The Lilienthal and Baruch reports were admirable and deserving of the support of all sane people. The reception given them, however, was not encouraging. The Russians suspected a trick. But, trick or no trick, the Soviet Government felt that the idea of unchecked international inspection was intolerable, and yet it is, of course, entirely obvious that apart from inspection any scheme of international control is utterly futile.
EINSTEIN'S COMMENT

The Lilienthal-Baruch proposal was a sensible and carefully worked out plan, which, as a first attempt at assurance against atomic attack certainly deserved better consideration on the part of Russia. On the other hand, it was difficult for the Russians to agree to the plan. First of all, it assumed that the demands it envisaged should be met immediately, whereas the formulation of methods and delivery of bomb piles were to be postponed to a time deemed suitable in the judgment of the United States. Secondly, the Russians undoubtedly fear that inspection of such wide scope, and in general the presence in their country of so many "westerners", would be a threat to Russia's inner balance. 
However reluctantly, I have been driven to the conclusion that the Soviet Government foresees within few years a situation in which it could win an atomic war. We may therefor expect its policy, if the West permits, to be one of temporizing until that time comes, while refusing steadfastly to agree to any plan which would make an atomic war impossible.

On the question of the international control of atomic energy, the public opinion of the world is opposed to the action of the Soviet Government. I think that America should take the lead in organizing a Grand Alliance of all those powers that are willing to consent to some such scheme as that set forth in the LiLiENTHAL report.

This ALLIANCE would, I am convinced, [continues below]

quickly come to embrace the whole world except Russia and her satellites It should then be [continues below]

possible to bring such pressure to bear upon Russia as would compel her to agree to the measure of international control that all other nations had accepted.

In spite of these limitations, I think the international control of atomic energy is an enormously important first step. It would, in the first place, show that an international organization concerned with war is possible, and would train a body of men possessing the knowledge and experience required for any kind of international government....
We cannot concur with the explanation in the paragraph inarked B, according to which Russia's refusal must be considered as motivated by her intention of undertaking an aggressive war at some later date. Publication of such a paragraph would necessarily increase the danger of a preventive war, which already haunts many people here.

We should try as little as possible to assign a role of LEADERSHIP to America, since a certain feeling of superiority has already spread in this country. If it should really be necessary to create a supra-national organization without Russia, it should not be an "alliance", but rather a kind of World Government with a centralized military power, not simply a realization of the Lilienthal report.

Could one not say, "the whole world, or at worst, the whole world, with the temporary exception of Russia and her satellites"?

Could one not speak here of "self interest" rather than "pressure"? Otherwise the existing enmity would only be furthered.

The supervisory personnel provided for by the Baruch-Lilientha plan surely could not be considered a nucleus for a world government. 